\title{
EFEKTYWNOŚĆ KLASYCZNYCH I ALTERNATYWNYCH AKCYJNYCH FUNDUSZY INWESTYCYJNYCH W ŚWIETLE ZMIAN USTAWY O FUNDUSZACH INWESTYCYJNYCH
}

\begin{abstract}
Abstrakt: W artykule poddano badaniu zmianę efektywności grupy alternatywnych funduszy inwestycyjnych w reakcji na wprowadzenie ustawy dotyczącej między innymi zmiany ustawy o funduszach inwestycyjnych. Aby zweryfikować hipotezę o pozytywnym wpływie tej ustawy na efektywność funduszy, wykorzystano narzędzia tak zwanej analizy zdarzeń. Jej wyniki potwierdziły dodatni wpływ regulacji na zarządzanie funduszami, ale tylko w krótkim okresie (do roku po zdarzeniu). Natomiast w długim horyzoncie czasowym nie zaobserwowano istotnych zmian w osiąganych wynikach.

Słowa kluczowe: alternatywne fundusze inwestycyjne, analiza zdarzeń, zagregowana dodatkowa stopa zwrotu, efektywność funduszy inwestycyjnych
\end{abstract}

\section{WSTĘP}

W dniu 4 czerwca 2016 roku weszła w życie ustawa z dnia 31 marca 2016 roku, która dotyczyła między innymi zmiany ustawy o funduszach inwestycyjnych. Jej celem było wdrożenie dyrektywy Parlamentu Europejskiego i Rady 2011/61/UE z dnia 8 czerwca 2011 roku w sprawie zarządzających alternatywnymi funduszami inwestycyjnymi ${ }^{1}$. Ustawa ta wprowadziła do polskiego prawa instytucję Alternatywnych Funduszy Inwestycyjnych (AFI) definiowaną jako instytucję wspólnego inwestowania, której przedmiotem działalności jest zbieranie aktywów od wielu inwestorów, by lokować je z korzyścią dla tych ostatnich i zgodnie z określoną polityką inwestycyjną. W Polsce zalicza się do tej kategorii specjalistyczne fundusze inwestycyjne otwarte, fundusze inwestycyjne zamknięte, alternatywne spółki inwestycyjne oraz unijne alternatywne fundusze inwestycyj-

${ }^{1}$ https://www.knf.gov.pl/dla_rynku/ASI (dostęp: 15.01.2021). 
$n^{2}$. Według ustawodawcy ten rodzaj działalności ma być od tej pory wykonywany pod nadzorem Komisji Nadzoru Finansowego, a podmioty posiadające status zarządzających alternatywnymi funduszami inwestycyjnymi będą zobowiązane do uzyskania zezwolenia Komisji Nadzoru Finansowego. Mimo że Dyrektywa objęła regulacją przede wszystkim nową grupę podmiotów, czyli Alternatywne Spółki Inwestycyjne (ASI), to warto zapytać, czy wprowadzenie nowej regulacji wpłynęło istotnie na wyniki dotychczas funkcjonujących podmiotów, jakimi są Specjalistyczne Fundusze Inwestycyjne Otwarte (SFIO).

Najpowszechniej stosowaną miarą efektywności inwestycji są wyniki uzyskiwane przez fundusz, a wyrażone osiągniętą stopą zwrotu, dlatego do weryfikacji stawianej hipotezy, że wprowadzenie dodatkowej regulacji pozytywnie wpłynęło na osiągane przez SFIO wyniki, wykorzystano analizę zdarzenia. Narzędzie to było wielokrotnie wykorzystywane w ocenie reakcji inwestorów na informacje o wydarzeniach mających miejsce w spółkach giełdowych, których podstawą była zmiana cen akcji. Metodologia ta jest często określana metodą dodatkowych stóp zwrotu $^{3}$ i polega na ocenie różnicy między rzeczywistą stopą zwrotu w okresie obserwacji a stopą oczekiwaną. Mimo że w literaturze przedmiotu stosuje się analizę zdarzeń przede wszystkim do badania efektów, jakie wywierają na rynku finansowe fuzje i przejęcia, to wydaje się, że ten sposób analizy może być również zastosowany w kontekście reakcji zarządzających funduszami na zmianę ustawodawczą. Jeśli okazałoby się mianowicie, że na skutek zmian dotyczących zarządzania SFIO, wyniki funduszy wzrosły w porównaniu z oczekiwanymi wynikami, to można by wnioskować, że zmiana prawna pozytywnie wpłynęła na zarządzających tą grupą funduszy, skutkując podniesieniem notowań samych funduszy (czego przykładowym rezultatem mogłaby być zmiana zarządzającego funduszem, zmiana dokonanych przez zarządzającego w portfelu aktywów czy też wykorzystanie przez niego technik timingowych). $Z$ kolei brak istotnych różnic pomiędzy wynikami mierzonymi zwrotem $\mathrm{z}$ inwestycji w fundusz świadczyłby o tym, że Dyrektywa nie ma wpływu na zarządzających.

Celem opracowania jest zatem potwierdzenie hipotezy, że wprowadzenie ustawy o AFI wpłynęło pozytywnie na poziom ich zarządzania przez Zarządzających. Aby tę hipotezę zweryfikować, zbadano skumulowane stopy zwrotu dla grupy akcyjnych SFIO na tle odpowiadających im otwartych funduszy inwestycyjnych (FIO), których bezpośrednio nie objęła Dyrektywa. Tak skonstruowana analiza miałaby na celu wyeliminowanie czynnika rynku. Jeśli okazałoby się, że obie grupy podobnie zareagowały na regulację prawną (przykładowo wzrostem wyników), to można by podejrzewać, że sam rynek pozwalał na osiągnięcie dodatkowych zwrotów bez względu na zdarzenie, jakim było wprowadzanie regulacji unijnej i dostosowanie zarządzających SFIO do Dyrektywy. Natomiast

2 Narodowy Bank Polski, Rozwój systemu finansowego w Polsce w 2017 r., oprac. K. Markowski, D. Tymoczko et al., Warszawa 2018.

3 S. Sudarsanam, Fuzje i przejęcia, Warszawa 1998, s. 219. 
inne zachowania dla obu grup potwierdziłyby, że analizowane zdarzenie mogło wpłynąć na zarządzających tymi instrumentami poprzez zwiększenie efektywności funduszy.

\section{ALTERNATYWNE FUNDUSZE INWESTYCYJNE}

W dniu 4 czerwca 2016 roku wdrożono do polskiego prawa nowelizację ustawy o funduszach inwestycyjnych. W jej skład wchodziły między innymi:

— dyrektywa 2011/61/UE w sprawie zarządzających alternatywnymi funduszami inwestycyjnymi (dyrektywa ZAFI),

— dyrektywa 2014/91/UE zmieniającej dyrektywę 2009/65/WE w sprawie koordynacji przepisów ustawowych, wykonawczych i administracyjnych odnoszących się do przedsiębiorstw zbiorowego inwestowania $\mathrm{w}$ zbywalne papiery wartościowe (UCITS) w zakresie funkcji depozytariusza, polityki wynagrodzeń oraz sankcji (dyrektywa UCITS V).

Ich celem było wprowadzenie ram prawnych, które regulowałyby zarówno funkcjonowanie, jak i nadzór wewnętrzny oraz zewnętrzny zarządzających alternatywnymi funduszami inwestycyjnymi, to jest zarządzających wszelkimi typami funduszy, które nie są objęte dyrektywą Parlamentu Europejskiego i Rady 2009/65/WE z dnia 13 lipca 2009 roku w sprawie koordynacji przepisów ustawowych, wykonawczych i administracyjnych odnoszących się do przedsiębiorstw zbiorowego inwestowania w zbywalne papiery wartościowe (UCITS) ${ }^{4}$. W tej jednej ustawie zostały więc uregulowane zarówno kwestie dotyczące przedsiębiorstw zbiorowego inwestowania $\mathrm{w}$ zbywalne papiery wartościowe, jak i kwestie innych form wspólnego inwestowania. Do pierwszej grupy przedsiębiorstw (UNITS) zakwalifikowane zostały otwarte fundusze inwestycyjne. Natomiast do nowej kategorii —zdefiniowanej jako alternatywne fundusze inwestycyjne (AFI) — ustawodawca zakwalifikował fundusze inwestycyjne zamknięte (FIZ), specjalistyczne fundusze inwestycyjne otwarte (SFIO) oraz tak zwane alternatywne spółki inwestycyjne (ASI). Do ostatniej z tych grup należą: spółki kapitałowe (spółki z ograniczoną odpowiedzialnością, spółki akcyjne, spółki europejskie), spółki komandytowe lub komandytowo-akcyjne, które pozyskują kapitał od wielu inwestorów w celu jego inwestowania zgodnie $\mathrm{z}$ określoną polityką inwestycyjną i w interesie tych inwestorów. Na skutek takiej kwalifikacji zdefiniowani zostali również zarządzający alternatywnymi funduszami inwestycyjnymi (ZAFI), którymi mogą być:

— towarzystwa funduszy inwestycyjnych zarządzające funduszami inwestycyjnymi zamkniętymi oraz specjalistycznymi funduszami inwestycyjnymi otwartymi,

${ }^{4}$ https://www.kancelaria-csw.pl/afi-nowa-kategoria-funduszy-inwestycyjnych (dostęp: 15.01.2021) 
— spółki kapitałowe spełniające warunki odnośnie prowadzonej działalności i w tym wypadku spółka będąca alternatywnym funduszem inwestycyjnym (AFI) jest równocześnie zarządzającym wewnętrznym funduszu,

- natomiast zewnętrznymi zarządzającymi AFI zostały osoby prawne będące jedynymi komplementariuszami spółek komandytowych i komandytowo-akcyjnych spełniających wymienione wyżej warunki odnośnie prowadzonej działalności.

Warto dodać, że w konsekwencji wprowadzonych zmian ten rodzaj działalności ma być wykonywany pod nadzorem Komisji Nadzoru Finansowego, a podmioty posiadające status zarządzających alternatywnymi funduszami inwestycyjnymi są zobowiązane do uzyskania zezwolenia Komisji Nadzoru Finansowego. A zatem zmiany te dotykają towarzystw funduszy inwestycyjnych oraz przedsiębiorców współpracujących z TFI lub zarządzanymi przez nie funduszami, zwiększając według autorów dyrektyw UCITS V oraz ZAFI — skuteczność działania funduszy inwestycyjnych nie tylko na krajowym, ale również i europejskim rynku usług finansowych. Dodatkowo regulacje te wpłyną na uporządkowanie rynku funduszy inwestycyjnych w państwach unijnych.

\section{METODOLOGIA BADANIA — ANALIZA ZDARZEŃ}

Analiza zdarzeń jest bezpośrednio związana z pojęciem rynku efektywnego informacyjnie. Efektywność informacyjna rynku zakłada, że bieżące ceny walorów w pełni odzwierciedlają wszystkie dostępne informacje. Obecnie rozważana jest ona zarówno w szerszym, jak i węższym znaczeniu, co dało możliwość sformułowania trzech hipotez efektywności rynku zdefiniowanych przez Eugene'a Francisa Famę, a rozróżnialnych ze względu na klasyfikację informacji zawierających się w zbiorze informacyjnym, względem którego hipoteza jest rozpatrywana:

1. hipoteza słabej efektywności rynkowej,

2. hipoteza półsilnej efektywności rynkowej,

3. hipoteza silnej efektywności rynkowej.

Narzędzia analizy zdarzeń należą do grupy metod służących weryfikacji półsilnej formy efektywności; analiza dotyczy oceny wpływu zdarzenia na zmiany wartości cen instrumentów finansowych. Mimo że metoda analizy zdarzeń ma ponad 40 lat, jej układ niezmiennie opiera się na klasycznej analizie zdarzeń zaproponowanej przez E.F. Famę, L. Fischera, R. Rolla i M.C. Jensena ${ }^{5}$. Kluczowy cel metody również pozostał bez zmian, a mianowicie celem jest pomiar skumu-

5 E.F. Fama et al., The Adjustment of Stock Prices to New Information, „International Economic Review" 1969, nr 10, s. 2-26. 
lowanej średniej dodatkowej stopy zwrotu w okolicach zdarzenia dla danej grupy akcji. Niezmienny pozostał oczywiście tylko cel główny i scenariusz postępowania; wraz z rozwojem metod statystycznych i dostępności danych, także metody szacowania dodatkowych stóp zwrotu, studium efektu ogłoszenia zdarzenia czy weryfikacja statystyczna uzyskanych wyników stały się bardziej zaawansowane i skomplikowane ${ }^{6}$. W tabeli 1. zamieszczono przykładowe badania wykorzystujące metody analizy zdarzeń.

Tabela 1. Wybrane badania wykorzystujące analizę zdarzeń na rynku finansowym

\begin{tabular}{|c|c|c|}
\hline Autor & Zdarzenie & Wynik badania \\
\hline G. Charest $^{7}$ & $\begin{array}{l}\text { Wpływ polityki wypłaty } \\
\text { dywidendy na rynku } \\
\text { amerykańskim. }\end{array}$ & $\begin{array}{l}\text { Ceny akcji spółek w dniu pojawienia informa- } \\
\text { cji o wzroście dywidendy zyskały na warto- } \\
\text { ści, natomiast po informacji o spadku wypłaty } \\
\text { dywidendy - straciły na niej. }\end{array}$ \\
\hline $\begin{array}{l}\text { A.A. Lonie, } \\
\text { G. Abeyratna, } \\
\text { D.M. Power, } \\
\text { C.D. Sinclair }\end{array}$ & $\begin{array}{l}\text { Wpływ polityki wypłaty dy- } \\
\text { widendy na rynku brytyj- } \\
\text { skim. }\end{array}$ & $\begin{array}{l}\text { Ceny akcji spółek w dniu pojawienia się infor- } \\
\text { macji o wzroście wypłaty dywidendy zyskały } \\
\text { na wartości, natomiast po informacji o spadku } \\
\text { wypłaty dywidendy — straciły na niej. }\end{array}$ \\
\hline \multirow{3}{*}{ A. Szyszka ${ }^{9}$} & $\begin{array}{l}\text { Wpływ nieoczekiwanej } \\
\text { zmiany kwartalnych } \\
\text { wyników finansowych. }\end{array}$ & $\begin{array}{l}\text { W okresie po zdarzeniu nie stwierdzono wys- } \\
\text { tępowania anormalnych stóp zwrotu. }\end{array}$ \\
\hline & $\begin{array}{l}\text { Wpływ korekty prognoz } \\
\text { finansowych. }\end{array}$ & Brak jednoznacznego wyniku. \\
\hline & $\begin{array}{l}\text { Wpływ publicznego wez- } \\
\text { wania do sprzedaży akcji. }\end{array}$ & $\begin{array}{l}\text { W okresie po zdarzeniu nie zaobserwowano } \\
\text { anormalnych stóp zwrotu. }\end{array}$ \\
\hline $\begin{array}{l}\text { T.D. Berry, } \\
\text { K.M. Howe }\end{array}$ & $\begin{array}{l}\text { Wpływ informacji publiko- } \\
\text { wanych w serwisie Reutera. }\end{array}$ & $\begin{array}{l}\text { Nie potwierdzono istotnej zależności pomię- } \\
\text { dzy liczbą informacji a zmiennością akcji na } \\
\text { rynku amerykańskim. }\end{array}$ \\
\hline
\end{tabular}

${ }^{6}$ A. Perepeczo, Analiza zdarzenia i jej zastosowania, „Zeszyty Naukowe Uniwersytetu Szczecińskiego. Finanse, Rynki Finansowe, Ubezpieczenia” 2011, nr 33, s. 35-51.

7 Charest G., Dividend information, stock returns and market efficiency II, „The Journal of Financial Economics" 1978, nr 2-3, s. 297-330.

8 A.A. Lonie, G. Abeyratna, D.M. Power, C.D. Sinclair, The stock market reaction to dividend announcement: a UK study of complex market signals, „The Journal of Economic Studies”23, 1996, nr 1, s. 32-52.

9 A. Szyszka, Efektywność Gietdy Papierów Wartościowych w Warszawie na tle rynków dojrzatych, Poznań 2003.

10 T.D. Berry, K.M. Howe, Public Information Arrival, „Journal of Finance” 1994, nr 49, s. $1331-1346$. 


\begin{tabular}{|c|c|c|}
\hline $\begin{array}{l}\text { J. Brzeszczyński } \\
\text { J. Gajdka, } \\
\text { A.M. Kutan }\end{array}$ & $\begin{array}{l}\text { Wpływ regularnych komu- } \\
\text { nikatów Narodowogo } \\
\text { Banku Polskiego na rynek } \\
\text { akcji i rynek walutowy }\end{array}$ & $\begin{array}{l}\text { Potwierdzenie spadku niepewności zarówno } \\
\text { na rynku walutowym, jak i na rynku } \\
\text { giełdowym po wygłoszeniu przez NBP } \\
\text { komunikatów. }\end{array}$ \\
\hline $\begin{array}{l}\text { D. Buttner, } \\
\text { B. Hayo }\end{array}$ & $\begin{array}{l}\text { Wpływ wiadomości } \\
\text { politycznych i makroeko- } \\
\text { nomicznych na rynki } \\
\text { finansowe w Czechach, na } \\
\text { Węgrzech i w Polsce. }\end{array}$ & $\begin{array}{l}\text { Szoki makroekonomiczne wpływają na krót- } \\
\text { koterminowe stopy procentowe. } Z \text { kolei szoki } \\
\text { polityczne i fiskalne aktualności wpływają } \\
\text { raczej na długoterminowe rentowności obli- } \\
\text { gacji oraz kursy walut i rynek giełdowy. }\end{array}$ \\
\hline
\end{tabular}

Źródło: opracowanie własne na podstawie cytowanej literatury.

W praktyce stosowane są dwa podejścia do tego typu badań. Mianowicie ocenia się reakcje rynku na z góry określone zdarzenia lub też wyróżnia się zaistniałą anomalię, a następnie szuka jej przyczyn w postaci zdarzenia (zdarzenie to może być natury zarówno ekonomicznej, jak i politycznej ${ }^{13}$ ). Metodologia analizy zdarzeń opiera się na założeniu, że wprowadzona na rynek nowa informacja powinna być bezzwłocznie dyskontowana przez rynek i mieć swoje odzwierciedlenie w cenie waloru, którego dotyczy. Oczywiście osobną kwestią jest zbadanie adekwatności reakcji waloru na nową informację. Często zdarza się, że dany instrument reaguje zbyt mocno albo zbyt łagodnie na wprowadzoną informację, wówczas następuje korekta jego kursu, co nazywane jest w literaturze przedmiotu anomaliami (sklasyfikowanymi w zależności od typu informacji).

Analizę zdarzenia przeprowadza się w określonych przedziałach czasowych względem okresu odniesienia. Aby poprawnie dokonać pomiaru dodatkowych stóp zwrotu, należy najpierw ustalić moment zdarzenia, względem którego będzie oceniany wzrost wartości, by w kolejnym kroku ustalić przedział czasowy mierzony w dniach, tygodniach lub miesiącach, który określany jest jako „okno zdarzenia". Ze względu na czas trwania przyjętego do badania okresu można wpływ zdarzenia oceniać w kontekście długo- jak i krótkookresowym. W literaturze przedmiotu okres krótkoterminowy najczęściej obejmował kilka lub kilkadziesiąt (ale nie więcej niż 60) dni przed i po ogłoszeniu informacji lub zaistnieniu zdarzenia. $Z$ kolei analiza długookresowa może obejmować czas od dwóch do pięciu lat po wydarzeniu. Warto dodać, że ogólna sytuacja oceny reakcji inwestorów nie opiera się na wynikach szczegółowych (dla pojedynczej spółki), ale na wynikach zagregowanych dla całej badanej populacji ${ }^{14}$.

11 J. Brzeszczyński, J. Gajdka, A.M. Kutan, Does Central Bank Communication Matter in Emerging European Markets? Evidence from Poland, „SSRN Electronic Journal” 2004, https:// dx.doi.org/10.2139/ssrn.2495791 (dostęp: 5.09.2021).

12 D. Buttner, B. Hayo, EMU-related news and financial markets in the Czech Republic, Hungary and Poland, „Applied Economics” 2012, nr 44, s. 4037-4053.

13 S.B. Buczek, Efektywność informacyjna rynków akcji. Teoria a rzeczywistość, Warszawa 2005.

14 A. Perepeczo, op. cit. 
Pomiar reakcji na nową informację mierzy się za pomocą nadwyżkowej stopy zwrotu, czyli stopy zwrotu z danego waloru pomniejszoną o stopę teoretycznego zwrotu z okresu, w którym nie wystąpiłaby dana anomalia:

$$
A R_{i t}=R_{i t}-E\left(R_{i t}\right)
$$

gdzie

$A R_{i t}$ - dodatkowa stopa zwrotu $\mathrm{z}$ waloru $i$ osiągnięta w okresie $t$,

$R_{i t}$ - rzeczywista stopa zwrotu $\mathrm{z}$ waloru $i$ osiągnięta w okresie $t$,

$E\left(R_{i t}\right)$ - oczekiwana stopa zwrotu $\mathrm{z}$ akcji $i$ w okresie $t \mathrm{w}$ sytuacji, gdyby zdarzenie nie wystąpiło.

Jeśli zatem dodatkowa stopa zwrotu dla waloru byłaby istotnie większa od zera, zdarzenie tworzyłoby dodatkową wartość dla inwestorów tego instrumentu. Gdyby była równa zeru, to można wnioskować o neutralnym efekcie zdarzenia, z kolei w sytuacji, gdy nadwyżkowa stopa zwrotu byłaby ujemna, można sądzić o negatywnym wpływie zdarzenia na kształtowanie się zwrotów z inwestycji. To samo rozumowanie można przeprowadzić w kontekście wpływu zaimplementowania dyrektywy unijnej na zarządzanie funduszami. Jej wprowadzenie miało za zadanie objąć kontrolą podmioty należące do AFI, a tym samym pozytywnie wpłynąć na sposób zarządzania nimi. Jeśli będzie możliwość zaobserwowania dodatnich nadwyżkowych stóp zwrotu z analizowanych funduszy po wprowadzeniu Dyrektywy, można będzie wnioskować o pozytywnym wpływie wprowadzonych zmian prawnych. Brak dodatkowych dodatnich zwrotów pokaże neutralność analizowanego zdarzenia na zarządzanie SFIO, z kolei ujemne dodatkowe zwroty będą stanowiły o negatywnym wpływie rozporządzenia.

W przedmiotowej literaturze wykorzystywane są dwa mierniki dodatkowej stopy zwrotu ${ }^{15}$ :

1. skumulowana dodatkowa stopa zwrotu (CAR),

2. tak zwane „kup i trzymaj”, czyli dodatkowa stopa zwrotu (BHAR).

Według Famy ${ }^{16}$ CAR jest lepszym miernikiem skumulowanej dodatkowej stopy zwrotu, ponieważ w jego przypadku test dodatkowej stopy zwrotu jest zgodny pod względem statystycznym z modelami szacowania oczekiwanej stopy zwrotu. Podobnego zdania byli Kothari i Warner ${ }^{17}$, którzy wskazywali, że BHAR jest obarczony większym błędem w ocenie niż CAR.

W związku z tym niniejszy artykuł podda analizie dodatkowe skumulowane stopy zwrotu wyznaczone według pierwszej metodologii, co oznacza, że skumu-

15 S. Sudarsanam, Creating Value from Mergers and Acquisitions. The Challenges: an Integrated and International Perspective, London 2003.

16 E.F. Fama, Market efficiency, long-term returns, and behavioral finance, „Journal of Financial Economics" 1998, nr 49, s. 283-306.

17 S.P. Kothari, J.B. Warner, Measuring long-horizon security price performance, „Journal of Financial Economics" 1997, nr 43, s. 301-339. 
lowana dodatkowa stopa zwrotu (CAR) będzie liczona jako suma tygodniowych dodatkowych stóp zwrotu w badanym okresie ${ }^{18}$ :

$$
C A R_{i T}=\sum_{t=1}^{T} A R_{i t}
$$

gdzie

$C A R_{i T}$ - skumulowana dodatkowa stopa zwrotu z waloru $i \mathrm{w}$ okresie $T$,

$A R_{i t}$ - dodatkowa stopa zwrotu $\mathrm{z}$ waloru $i$ osiągnięta w okresie $t$,

$T$ - okres obserwacji mierzony w tygodniach.

W kolejnym kroku wyznaczana jest zagregowana dodatkowa stopa zwrotu dla całej populacji (w tym przypadku dla grupy funduszy inwestycyjnych) jako średnia arytmetyczna skumulowanych stóp zwrotu wszystkich analizowanych funduszy:

$$
A C A R_{i T}={ }_{N}^{\overline{1}} \sum_{t=1}^{T} C A R_{i t}
$$

gdzie

$A C A R_{i T}$ - średnia skumulowanych dodatkowych stóp zwrotu, $N$ - liczba funduszy poddanych analizie.

Warto w tym miejscu podkreślić, że kluczową rolę w analizie zdarzeń odgrywa dodatkowa stopa zwrotu. Aby wyznaczyć jej wartość, należy obliczyć rzeczywistą, a następnie oczekiwaną stopę zwrotu. Drugi rachunek jest dużo bardziej skomplikowany, ponieważ polega na znalezieniu stopy dochodu osiąganej przez fundusz w okresie, w którym nie były odczuwalne skutki zdarzenia, czyli przy założeniu, że zdarzenie nie wystąpiło. W literaturze przedmiotu są proponowane różne podejścia do kwestii wyznaczenia oczekiwanej stopy zwrotu ${ }^{19}$ :

— stopa zwrotu z indeksu rynkowego w „oknie zdarzeń” (model skorygowany o rynek);

— średnia stopa zwrotu z waloru w okresie niezależnym (model skorygowany o średnią);

- stopa wyznaczona z modelu CAPM;

- stopa wyznaczona z trójczynnikowego modelu Famy-Frencha;

— zrealizowana stopa zwrotu dla grupy spółek o podobnym charakterze (model portfelowy);

18 B.M. Barber, J.D. Lyon, Detecting long-run abnormal stock returns. The empirical power and specification of test statistics, ,Journal of Financial Economics” 1997, nr 43.

19 S. Sudarsanam, Creating Value from Mergers... 
— stopa zwrotu z tak zwanej spółki kontrolnej, która nie bierze udziału w zdarzeniu, ale jest spółką porównywalną z naszym walorem (na przykład ze względu na wielkość czy rodzaj działalności) - model spółki kontrolnej.

Do wyznaczenia oczekiwanej stopy zwrotu $\mathrm{z}$ funduszy wykorzystano w pracy stopę pochodzącą z klasycznego modelu wyceny kapitału (CAPM). Model ten ma za zadanie wyjaśnić wielkość osiągniętych stóp zwrotu z papierów wartościowych jako funkcji rynkowego ryzyka ${ }^{20}$. Model ten zakłada, że kształtowanie się wielkości stóp zwrotu $\mathrm{z}$ waloru jest zdeterminowane czynnikiem odzwierciedlającym zmiany na rynku kapitałowym. Wówczas oczekiwaną stopę zwrotu na podstawie tego modelu szacuje się jako:

$$
E\left(R_{i, t}\right)=\alpha+\beta \cdot\left(R_{M, t}-R_{f t}\right)+R_{f t}
$$

gdzie

$E\left(R_{i, t}\right)$ - oczekiwana stopa zwrotu $\mathrm{z}$ waloru $i$ w okresie $t$,

$R_{M, t}-R_{f t}$ - nadwyżkowa stopa zwrotu z indeksu rynku w chwili $t$ nad stopę wolną od ryzyka,

$$
\begin{gathered}
R_{f t} \text { - stopa zwrotu instrumentu wolnego od ryzyka, } \\
R_{M, t} \text { - topa zwrotu z indeksu rynkowego w okresie } t .
\end{gathered}
$$

Model CAPM był wielokrotnie wykorzystywany w badaniach nad wpływem informacji na kształtowanie się zwrotów z inwestycji. Przykładami tego typu prac są między innymi artykuły Goergen i Renneboog ${ }^{21}$ czy Xu, Jin i Li ${ }^{22}$.

\section{WPŁYW WPROWADZENIA DYREKTYWY NA EFEKTYWNOŚĆ FUNDUSZY - WYNIKI PRZEPROWADZONEJ ANALIZY}

Analizie poddano 28 akcyjnych Specjalistycznych Funduszy Inwestycyjnych oraz 36 Otwartych Funduszy Inwestycyjnych Akcji o zróżnicowanej polityce inwestycyjnej (zarówno uniwersalnych, jak i małych oraz średnich przedsiębiorstw), które były notowane w okresie od stycznia roku 2013 do lutego 2020 roku. Na podstawie tygodniowych notowań tych walorów (dostępnych na stronie www. stooq.pl) zostały obliczone logarytmiczne tygodniowe stopy zwrotu, na których zostały oparte dalsze analizy. Warto podkreślić, że duże znaczenie w procesie oceny wyników funduszy inwestycyjnych mają wzorce odniesienia (tak zwane benchmarki). W związku z tym istotnego znaczenia nabierają prawidłowa budowa i dobór odpowiednich elementów wzorca odniesienia tak, aby mógł on służyć

20 F.K. Reilly, K.C. Brown, Analiza inwestycji i zarzadzanie portfelem, t. 2, Warszawa 2001.

21 M. Goergen, L. Renneboog, Shareholder Wealth Effects of European Domestic and Crossborder Takeover Bids, „European Financial Management” 2014, nr 1.

22 T. Xu, J.J. Jin., D. Li, Long-term market reactions to earnings restatements, „Academy of Accounting and Financial Studies Journal” 2009, nr 13. 
w procesie oceny poszczególnych typów funduszy inwestycyjnych. Z uwagi na złożoność powyższych czynników konstrukcja właściwego wzorca odniesienia dla danej grupy funduszy może okazać się zagadnieniem niezwykle skomplikowanym, jednak stworzenie idealnego wzorca odniesienia dla wszystkich funduszy inwestycyjnych nie jest możliwe ${ }^{23}$. Prawie wszystkie sposród publikowanych prospektów inwestycyjnych określają wzorzec odniesienia dla swoich funduszy, co ułatwia ocenę efektywności zarządzania nimi. Komplikację stanowią fundusze, które często zmieniają politykę inwestycyjną lub określają benchmark w taki sposób, że nie odzwierciedla on w pełni prowadzonej przez nie polityki inwestycyjnej. Informację na temat benchmarku analizowanych funduszy i ich polityki inwestycyjnej zaczerpnięto ze strony www.analizy.pl. Na ich podstawie stworzone zostały wzorce rynkowe służące dalszej ocenie, natomiast jako stopę wolną od ryzyka wykorzystano stope zwrotu z dziesięcioletnich obligacji skarbowych.

W celu weryfikacji postawionej hipotezy w dalszej części analizy wyłoniono osiem okresów badawczych, cztery przed wprowadzeniem regulacji:

- B_3 - obejmujący okres trzech lat przed wprowadzeniem regulacji;

- B 2 - obejmujący okres dwóch lat przed wprowadzeniem regulacji;

- B_1 - obejmujący okres roku przed wprowadzeniem regulacji;

- B_0.5 - obejmujący okres półrocza przed wprowadzeniem regulacji oraz cztery po jej wprowadzeniu:

—A_0.5 - obejmujący okres półrocza po wprowadzeniu regulacji;

- A_1 - obejmujący okres roku po wprowadzeniu regulacji;

-A_2 - obejmujący okres dwóch lat po wprowadzeniem regulacji;

-A_3 - obejmujący okres trzech lat po wprowadzeniem regulacji.

Okres miesiąca, w którym ustawa weszła w życie, nie został objęty oceną, pełniąc tym samym rolę „okna zdarzeń”.

W pierwszym kroku na podstawie tygodniowych logarytmicznych stóp zwrotu wybranych funduszy, ich benchmarku oraz dla okresów poprzedzających wprowadzenie Dyrektywy zostały oszacowane parametry modelu CAPM:

$$
R_{i, t}-R_{f t}=\alpha+\beta \cdot\left(R_{M, t}-R_{f t}\right)+\varepsilon_{t}
$$

Parametry modelu szacowano dla odpowiednich podokresów, stąd też cztery zestawy: ryzyka systematycznego $(\beta)$ oraz wskaźnika Jensena $(\alpha)$. Dla większości funduszy - zarówno otwartych, jak i specjalistycznych otwartych — wyraz wolny w modelu wyceny kapitału był nieistotny statystycznie (średnio 5\% funduszy w każdym okresie miało istotny wyraz wolny), dlatego w tabeli 2 . zobrazowano wartości statystyk jedynie dla ryzyka systematycznego, które we wszystkich funduszach było istotne statystycznie $(p<0.0001)$.

23 R. Haugen, Teoria nowoczesnego inwestowania, Warszawa 1996. 
Tabela 2. Statystyki opisowe ryzyka systematycznego dla analizowanych funduszy

\begin{tabular}{|l|c|c|c|c|}
\hline \multicolumn{1}{|c|}{ SFIO } & B_0.5 & B_1 & B_2 & B_3 \\
\hline średnia & 0,9426 & 0,9570 & 0,9670 & 0,9679 \\
\hline odchylenie standardowe & 0,1280 & 0,0828 & 0,0628 & 0,0719 \\
\hline mediana & 0,9904 & 0,9908 & 0,9940 & 0,9943 \\
\hline Q1 & 0,9374 & 0,9562 & 0,9491 & 0,9387 \\
\hline Q3 & 1,0036 & 1,0011 & 0,9990 & 0,9991 \\
\hline max & 1,1121 & 1,0811 & 1,0470 & 1,0350 \\
\hline min & 0,6061 & 0,7308 & 0,7983 & 0,8097 \\
\hline skośność & $-1,7328$ & $-1,9809$ & $-1,8501$ & $-1,0169$ \\
\hline & B_0.5 & B_1 & B_2 & B_3 \\
\hline średnia & 0,9108 & 0,9344 & 0,9606 & 0,9623 \\
\hline odchylenie standardowe & 0,1290 & 0,0856 & 0,0565 & 0,0544 \\
\hline mediana & 0,9496 & 0,9560 & 0,9678 & 0,9726 \\
\hline Q1 & 0,8845 & 0,9087 & 0,9423 & 0,9336 \\
\hline Q3 & 0,9856 & 0,9849 & 1,0005 & 0,9984 \\
\hline max & 1,2495 & 1,1228 & 1,0861 & 1,0567 \\
\hline min & 0,5612 & 0,6534 & 0,7343 & 0,7518 \\
\hline skośność & $-0,6561$ & $-1,1310$ & $-1,2724$ & $-2,0195$ \\
\hline
\end{tabular}

Źródło: opracowanie własne na podstawie danych pochodzących ze stron www.stooq.pl i www.analizy.pl.

Wartości parametru beta były bardzo wysokie (średnio na poziomie 0.95 ), co tak naprawdę nie powinno zaskakiwać, ponieważ do analizy zostały wciągnięte fundusze akcyjne charakteryzujące się najwyższą ekspozycją na ryzyko. Warto zauważyć, że wraz ze wzrostem długości okresu szacowania parametrów średnie ryzyko $\mathrm{w}$ grupie $\mathrm{z}$ jednej strony wzrastało, $\mathrm{z}$ drugiej natomiast zmniejszało się jego rozproszenie mierzone odchyleniem standardowym. Również rozstęp pomiędzy wartościami skrajnymi malał wraz z wydłużaniem się okresu estymacji.

Na podstawie parametrów regresji uzyskanych w kroku pierwszym, w kolejnym etapie (na podstawie wartości rynkowych oraz wolnych od ryzyka stóp zwrotu) zostały oszacowane oczekiwane stopy zwrotu z inwestycji w poszczególne fundusze FIO i SFIO (wzór (4)). Następnie, zgodnie ze wzorem (1), na ich podstawie zostały obliczone nadwyżkowe stopy zwrotu $(A R)$ oraz skumulowane nadwyżkowe stopy zwrotu (CAR - wzór (2)). Skumulowana dodatkowa stopa zwrotu $C A R$ : 
— dla okresu półrocznego była wyznaczana na podstawie nadwyżkowych stóp zwrotu szacowanych dla zestawu parametrów modelu CAPM dotyczącego półrocznego okresu poprzedzającego wprowadzenie Dyrektywy (B_0.5),

- dla okresu rocznego była wyznaczana na podstawie nadwyżkowych stóp zwrotu szacowanych dla zestawu parametrów modelu CAPM dotyczącego rocznego okresu przed wprowadzeniem Dyrektywy (B_1),

- dla okresu dwuletniego była wyznaczana na podstawie nadwyżkowych stóp zwrotu szacowanych dla zestawu parametrów modelu CAPM dotyczącego dwuletniego okresu przed wprowadzeniem Dyrektywy (B 2),

- dla okresu trzyletniego była wyznaczana na podstawie nadwyżkowych stóp zwrotu szacowanych dla zestawu parametrów modelu CAPM dotyczącego trzyletniego okresu przed wprowadzeniem Dyrektywy (B_3),

Ich rozkład w poszczególnych grupach funduszy zobrazowano na wykresie 1.

Rysunek 1. Rozkład skumulowanych dodatkowych stóp zwrotu dla FIO i SFIO

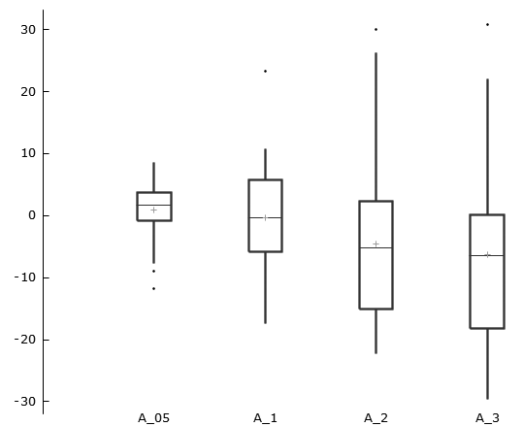

FIO

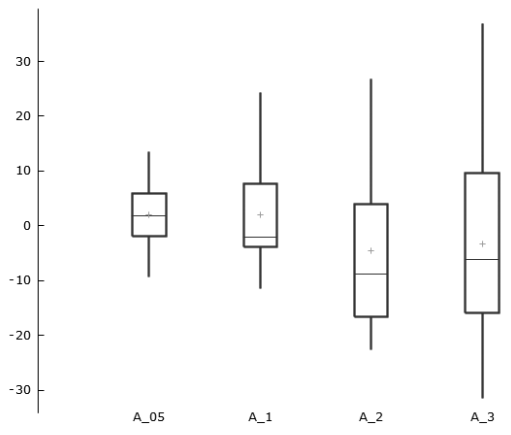

SFIO

Źródło: opracowanie własne.

Nietrudno zauważyć, że kształtowanie się stóp CAR charakteryzuje się podobnymi tendencjami w poszczególnych podokresach dla SFIO oraz FIO, co może sugerować, że nie ma widocznego związku pomiędzy wynikami funduszy SFIO a wprowadzeniem Dyrektywy. W związku z tym w kolejnym kroku poddano weryfikacji hipotezę, że wprowadzenie nowej Dyrektywy ZAFI pozytywnie wpłynęło na sposób zarządzania AFI poprzez zwiększenie ich efektywności. W tym celu przeprowadzono test zerowej wartości oczekiwanej dodatkowych stóp zwrotu $(A C A R)$ dla odpowiednich podokresów $(\mathrm{H} 0)$, z hipotezami alternatywnymi, że $A C A R$ była niezerowa (H1) lub że średnie skumulowane dodatkowe stopy zwrotu osiągane przez grupy funduszy w okresach po wprowadzeniu dyrektywny były dodatnie lub ujemne (H2). Zbadano tym samym zmianę efektywności funduszy w krótkim (półrocznym), średnim (rocznym) i długim (dwu- oraz trzyletnim) odcinku czasu. Wyniki wnioskowania zamieszczono w tabeli 3. 
Tabela 3. Zagregowana dodatkowa stopa zwrotu dla FIO i SFIO wraz z wynikami testu wartości oczekiwanej

\begin{tabular}{|c|c|c|c|c|c|}
\hline grupa & miara & A_0.5 & A_1 & A_2 & A_3 \\
\hline \multirow{4}{*}{$\frac{0}{\sqrt{\sim}}$} & średnia & 2,0146 & 1,9152 & $-4,4982$ & $-3,3444$ \\
\hline & wartość statystyki testowej $\mathrm{T}$ & 2,0587 & 1,8742 & $-1,8987$ & $-1,8720$ \\
\hline & $\mathrm{H} 1$ - wartość $\mathrm{p}$ & 0,0463 & 0,0684 & 0,0650 & 0,0903 \\
\hline & $\mathrm{H} 2$ - wartość $\mathrm{p}$ & 0,0231 & 0,0342 & 0,0325 & 0,0452 \\
\hline \multirow{4}{*}{$\stackrel{ }{\underline{I}}$} & średnia & 0,9216 & $-0,3988$ & $-4,5031$ & $-6,3510$ \\
\hline & wartość statystyki testowej T & 1,2840 & $-0,3017$ & $-2,3017$ & $-3,0210$ \\
\hline & $\mathrm{H} 1$ - wartość $\mathrm{p}$ & 0,2069 & 0,7645 & 0,0269 & 0,0045 \\
\hline & $\mathrm{H} 2$ - wartość $\mathrm{p}$ & 0,1035 & 0,3823 & 0,0135 & 0,0022 \\
\hline
\end{tabular}

Źródło: opracowanie własne.

Zgodnie z przewidywaniami nie ma widocznego związku pomiędzy wynikami FIO, których Dyrektywa bezpośrednio nie dotknęła, a momentem jej wprowadzenia. W krótkim i średnim odcinku czasu po zdarzeniu zagregowana dodatkowa stopa zwrotu dla całej tej grupy była istotnie różna od zera, co świadczy o neutralności analizowanego zdarzenia na zarządzanie FIO wyrażone w wynikach funduszy. Natomiast ciekawy efekt ujawnił się w grupie SFIO, a mianowicie w krótkim i średnim okresie czasu (półrocze i rok) $A C A R$ dla tej grupy był istotnie różny od zera. Więcej nawet: był istotnie dodatni, co oznacza, że obserwowany był pozytywny wpływ wprowadzonych zmian prawnych. Natomiast w pozostałych okresach (inwestycje długookresowe) obie grupy funduszy po pierwsze osiągały ujemne wyniki, po drugie - zagregowane dodatkowe stopy zwrotu w tych grupach były istotnie ujemne, co może świadczyć o tym, że to nie Dyrektywa wpłynęła negatywnie na efektywność funduszy, lecz ogólna sytuacja rynkowa.

\section{ZAKOŃCZENIE}

Według nowych zasad powierzenie funkcji zarządzania funduszem może być dokonane przez TFI na rzecz podmiotów, które spełniają ustawowe wymogi oraz posiadają odpowiednie środki organizacyjne i finansowe dla zabezpieczenia interesu inwestora. Takiego powierzenia - między innymi w ramach SFIO — można dokonać jedynie na rzecz profesjonalnego brokera lub innego TFI odrębnie autoryzowanego przez KNF. Przeprowadzona analiza świadczy, że Zarządzający zareagowali na wprowadzenie nowej Dyrektywy, jednak pozytywny kierunek zmian w zarządzaniu SFIO zauważyć można było jedynie krótko po wprowadzeniu no- 
wego aktu prawnego (do roku). Gdy spojrzymy na problem długookresowo, nietrudno zaobserwować, że efektywność mierzona dodatkowymi zwrotami zmalała, co może świadczyć o tym, że reakcja menedżerów była jedynie chwilowa i że po okresie przejściowym oraz ustabilizowaniu się sytuacji na rynku AFI zdecydowali się powrócić do wcześniejszego sposobu zarządzania.

Mimo że Dyrektywa najbardziej dotknęła nową grupę podmiotów, to jest Alternatywne Spółki Inwestycyjne (ASI), to również w przypadku SFIO wprowadzenie nowej regulacji zostało zauważone przez ich zarządzających, o czym świadczy kształtowanie się obliczonych mierników ACAR w grupie badawczej SFIO na tle grupy kontrolnej FIO. Problem oceny efektywności badanych jednostek, których działalność ma być wykonywana pod nadzorem KNF, wydaje się być interesujący przede wszystkim ze względu na wpływ, jaki nowe zaostrzenia wywarły na sposób zarządzania AFI. W przyszłości badanie zostanie więc rozszerzone na pozostałe podmioty należące do tej grupy.

\title{
EFFICIENCY OF CLASSICAL AND ALTERNATIVE EQUITY INVESTMENT FUNDS IN LIGHT OF THE AMENDMENTS TO THE ACT ON INVESTMENT FUNDS
}

\begin{abstract}
Summary
The article analyses the changes in the effectiveness of a group of alternative stock investment funds on the implementation of a law concerning, among other things, the amendment of the Law on Investment Funds. In order to verify the hypothesis on the positive effect of this law on the efficiency of the funds, the tools of event study were used. The results of the analysis verified the positive effect of the regulation on fund management, but only in the short term (up to one year after the event). However, in a long time horizon no significant changes in the achieved results were observed.
\end{abstract}

Keywords: alternative investment funds, event study, aggregate additional rate of return, investment fund efficiency

\section{BIBLIOGRAFIA}

Barber B.M., Lyon J.D., Detecting long-run abnormal stock returns. The empirical power and specification of test statistics, „Journal of Financial Economics” 1997, nr 43.

Berry T.D., Howe K.M., Public Information Arrival, „Journal of Finance” 1994, nr 49, s. 13311346.

Brzeszczyński J., Gajdka J., Kutan A.M, Does Central Bank Communication Matter in Emerging European Markets? Evidence from Poland, ,SSRN Electronic Journal” 2004, https://dx.doi. org/10.2139/ssrn.2495791 (dostęp: 5.09.2021).

Buczek S.B., Efektywność informacyjna rynków akcji. Teoria a rzeczywistość, Warszawa 2005.

Buttner D., Hayo B., EMU-related news and financial markets in the Czech Republic, Hungary and Poland, „Applied Economics” 2012, nr 44, s. 4037-4053. 
Charest G., Dividend information, stock returns and market efficiency II, „The Journal of Financial Economics" 1978, nr 2-3, s. 297-330.

Dyrektywy Parlamentu Europejskiego i Rady 2011/61/UE z dnia 8 czerwca 2011 roku w sprawie zarządzających alternatywnymi funduszami inwestycyjnymi.

Fama E.F., Market efficiency, long-term returns, and behavioral finance, ,Journal of Financial Economics" 1998, nr 49, s. 283-306.

Fama E.F., Fischer L., Jensen M.C., Roll R., The Adjustment of Stock Prices to New Information, „International Economic Review” 1969, nr 10, s. 2-26.

Goergen M., Renneboog L., Shareholder Wealth Effects of European Domestic and Cross-border Takeover Bids, „European Financial Management” 2014, nr 1.

Haugen R., Teoria nowoczesnego inwestowania, Warszawa 1996.

Kothari S.P., Warner J.B., Measuring long-horizon security price performance, „Journal of Financial Economics" 1997, nr 43, s. 301-339.

Lonie A.A., Abeyratna G., Power D.M., Sinclair C.D., The stock market reaction to dividend announcement: a UK study of complex market signals, „The Journal of Economic Studies” 23, 1996, nr 1, s. 32-52.

Narodowy Bank Polski, Rozwój systemu finansowego w Polsce w 2017 r., oprac. K. Markowski, D. Tymoczko et al., Warszawa 2018.

Perepeczo A., Analiza zdarzenia i jej zastosowania, „Zeszyty Naukowe Uniwersytetu Szczecińskiego. Finanse, Rynki Finansowe, Ubezpieczenia" 2011, nr 33, s. 35-51.

Reilly F.K., Brown K.C., Analiza inwestycji i zarzadzanie portfelem, t. 2, Warszawa 2001, s. 195.

Sudarsanam S., Fuzje i przejęcia, Warszawa 1998.

Sudarsanam S., Creating Value from Mergers and Acquisitions. The Challenges: an Integrated and International Perspective, London 2003.

Szyszka A., Efektywność Giełdy Papierów Wartościowych w Warszawie na tle rynków dojrzatych, Poznań 2003.

$\mathrm{Xu}$ T., Jin J.J., Li D., Long-term market reactions to earnings restatements, „Academy of Accounting and Financial Studies Journal” 2009, nr 13.

\section{ŹRÓDŁA INTERNETOWE}

www.analizy.pl.

www.newconnect.pl.

https://www.knf.gov.pl/dla_rynku/ASI.

https://www.kancelaria-csw.pl/afi-nowa-kategoria-funduszy-inwestycyjnych. 